\title{
Current state of lakes in Northern Yakutia (diatom algae and abiotic parameters)
}

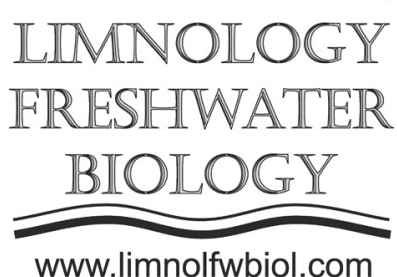

\author{
Gorodnichev R.M.*, Pestryakova L.A., Ushnitskaya L.A., Levina C.N., Davydova P.V.
}

M.K. Ammosov North-Eastern Federal University, Belinskogo Str. 58, Yakutsk, 677000, Russia

\begin{abstract}
The review shows the definition of morphometric characteristics, water chemical parameters and diatom assemblages of lakes located in the Arctic zone of Yakutia, in catchments of Anabar, Olenek, Lena, Indigirka and Kolyma Rivers. Main amount of these lakes has small water areas and low depth. The lakes are ultra fresh and mainly with neutral $\mathrm{pH}$, characterized by moderate transparency (on average $43 \%$ of a maximum water depth) and increased concentrations of total iron, silicon, phosphate and ammonium ions. More than the half of the lakes are characterized by exceed of the fishery limits in total iron and phosphate concentrations. In most cases, the dominant major ions are hydrocarbonates and calcium. 502 species and subspecies of 92 genera of diatoms have been discovered in the studied lakes. The highest number of species are included in such genera as Eunotia (38 taxa), Pinnularia (33), Nitzschia (30), Navicula (29), Gomphonema (20) and Achnanthes (17). The most broadly occurred species Tabellaria flocculosa, T. fenestrata, Staurosirella pinnata, Staurosira venter, $S$. construens, Achnanthidium minutissimum and Eunotia praerupta. Diatom assemblages of the lakes are characterized by a rather high diversity and evenness. The Pantle-Buck saprobity index, calculated inferred from known values of indicative significance of diatoms, indicates that most of the lakes have clean water. Water of $16.9 \%$ lakes is moderate polluted.
\end{abstract}

Keywords: Yakutia, lake, diatom algae, Arctic, saprobity

\section{Introduction}

Although Yakutia is the biggest region of the Russian Federation, the North of the subject is poorly investigated territory with a lot of different kinds of natural ecosystems, one of the most sensitive ones are lakes. They are the source of fresh water resources and place for numerous living organisms which form a complex of different relationships, in which diatom algae (Bacillariophyta) play a key role as one of the most important energetic and food producer (Smol and Douglas, 2007). Taking in account the importance of the lake ecosystems and their diatoms, we have prepared description of general morphometric parameters of the lakes, chemical characteristics of their water and features of diatoms.

\section{Materials and methods}

The paper describes the condition of 83 lakes located in the North of Yakutia, in the basins of Anabar, Olenek, Lena, Indigirka and Kolyma Rivers. The investigated district is a weakly engaged in industry, but has great potential for such aims. The field stages of the study were implemented in the summer period (July-
August) from 2002 to 2012 under a unified program of field studies. Water samples for chemical analysis have been taken in the top layer of water $(0.2-0,5 \mathrm{~m}$ below surface) in sterile plastic bottles. Diatom algae were observed in the uppermost $(0-0.2 \mathrm{~cm})$ bottom sediments which have been taken by Ekman sediment grabber and gravity corer UWITEC.

\section{Results}

Morphometric parameters of the lakes vary widely. The majority of the lakes $(58 \%)$ have very shallow depth $(<3.12 \mathrm{~m}), 64 \%$ of water ecosystems have the shape of water surface close to rounded (Grigor'ev ratio $=1.5-3.0)$. $82 \%$ of studied lakes are small $\left(0.1-1 \mathrm{~km}^{2}\right)$ and very small lakes $\left(<0.1 \mathrm{~km}^{2}\right)$. The water transparency changes in wide limits from 0.2 to $4.5 \mathrm{~m}$ at the averaging $1.3 \mathrm{~m}$. In terms of the average transparency to maximum water depth ratio (0.43), the set of lakes can be characterized as lakes with moderate transparency. The water of lake ecosystems has rather high concentrations of total iron $(0.3 \mathrm{mg} / 1$ on average), silicon $(1.1 \mathrm{mg} / \mathrm{l})$, phosphate $(0.1 \mathrm{mg} / \mathrm{l})$ and ammonium $(0.3 \mathrm{mg} / \mathrm{l})$. According to the mean concentrations of the chemical components, it can be 
described as ultra fresh, very soft with neutral $\mathrm{pH}$ and prevailation of hydrocarbonate and calcium ions. More than the half of the lakes are characterized by excess of the fishery limits in dissolved in water phosphates (limit for oligotrophic waters) and total iron. Such high concentrations of the parameters can be considered as a result of the natural reasons due to the remoteness of the water objects from settlements and economically developed territories. Concentrations of silicon, ions of the salinity and total hardness decrease in the study area from the South to the North. Such zonal trends are probably the result of changes in precipitation.

The studied lakes are represented by quite high number of species and variations (502 species and subspecies) of algae from 92 genera of Bacillariophyta. The most abundant, in number of species, genera are Eunotia (38 taxa), Pinnularia (33), Nitzschia (30), Navicula (29), Gomphonema (20) and Achnanthes (17). The lakes ecosystems have a rather high specificity (dissimilarity) of diatom species composition, for which the role of main unifying component belongs to common "mass" taxa, well adapted to the environment. The highest frequency as dominants have been marked for Tabellaria flocculosa (in 28 lakes), Staurosirella pinnata (in 22), Staurosira venter (in 10), S. construens (in 9), Tabellaria fenestrata (in 8), Achnanthidium minutissimum (in 7) and Eunotia praerupta (in 7). The diversity and evenness of diatoms from lake ecosystems in North Yakutia can be evaluated as high.

Using species and subspecies of diatom algae with known values of saprobity, the saprobity the Puntle-Buck index has been calculated. The values of the index vary from 0.63 to 1.81 , the averaging 1.27. According to the parameter all lakes have been grouped into 2 categories: oligosaprobic lakes (83.1\% or 69 lakes, saprobity index is from 0.51 to 1.5 ) and $\beta$-mesosaprobic water reservoirs $(16.9 \%$ or 14 objects, value of the index is from 1.51 to 2.5 ). In general, average meanings of the saprobity index of the lakes are distributed quite evenly over the territory of the study area from 1.1 to 1.5 and characterize the lake ecosystems as oligosaprobic or having clean water.

\section{Conclusions}

The results of the study show that the most part of the investigated lakes have small sizes and rounded shape. Their water contain low quantities of minerals and has prevail neutral $\mathrm{pH}$. Although, all lakes located far away from the economically developed places, waters of $16.9 \%$ of them are polluted. Such pollution may be a result of natural reasons, a consequence of lake development and changing of their trophic status.

\section{Acknowledgements}

The study has been carried out in framework of the project FSRG-2020-0019 fonded by Ministry of Science and Higher Education of the Russian Federation and RFBR grant No 15-45-05063 r_vostok_a fonded by the Russian Foundation for Basic Research.

\section{References}

Smol J.P., Douglas M.S.V. 2007. Crossing the final ecological threshold in High Arctic ponds. Proceedings of the National Academy of Sciences of the USA 104: 12395-12397. 